\title{
Is internationally recognised independence the goal of quasi-states? The case of Transnistria
}

Abstract

Some students of quasi-states say that these entities aim to obtain the acceptance of their independence by the international community. However, this thesis raises doubts, at least in case of Transnistria, a region with its capital in Tiraspol, that began functioning as a quasi-state in mid-1992 after gaining victory in a brief war with Moldova. The paper's goal is to answer whether Transnistria really seeks international recognition as an independent state. It examines the position of two Transnistrian presidents - dominant figures in Transnistria's political system-Igor Smirnov (19912011) and Yevgeniy Shevchuk (since December 2011), as well as of the party Obnovleniye (Renewal) which has controlled the Transnistrian parliament since 2005 . The paper concludes that despite official declarations made by the Transnistrian authorities about seeking internationally recognised independence for their region, this nominal goal is not necessarily a real one. Generally, they position concerning Transnistria's status is not so easily identified. They seem to be in favour of keeping the status quo and maintaining the quasi-state's de facto independence. However, it appears that under conditions securing Transnistria's rights and interests, the present Transnistrian president, Shevchuk, and the parliament controlled by the party Obnovleniye could truly support the idea of reintegration with Moldova.

Quasi-states resemble normal states except for one difference: they lack international recognition or enjoy it only at a minimal level. This means that their territories formally belong to universally recognised 
states, although in reality the authorities of these parent states have no control over their breakaway regions. Examples of quasi-states are as follows: Northern Cyprus located in the territory of the Republic of Cyprus, Nagorno-Karabakh in Azerbaijan, Transnistria in Moldova, Abkhazia and South Ossetia in Georgia, and Somaliland in Somalia.

Some students of quasi-states explicitly (Kolstø 2006: 725-726; Caspersen 2011: 337; Steinsdorff, Fruhstorfer 2012: 117) or implicitly (Kolossov, O'Loughlin 1999: 151-152) say that these entities aim to obtain acceptance of their independence by the international community. However, this thesis raises doubts, at least in the case of Transnistria, a region with its capital in Tiraspol, which began functioning as a quasi-state in mid-1992 after victory in a brief war with Moldova. ${ }^{1}$ The goal of this paper is to answer whether Transnistria really seeks international recognition as an independent state. It examines the position of two Transnistrian presidents-dominant figures in Transnistria's political system-Igor Smirnov (1991-2011) and Yevgeniy Shevchuk (since December 2011), as well as of the party Obnovleniye (Renewal). Obnovleniye formed the opposition to both heads of the quasi-state, as it has been in control of the Transnistrian parliament since 2005 .

\section{IGOR SMIRNOV AND TRANSNISTRIA's INDEPENDENCE}

In the period between the end of the war with Moldova in mid-1992, and Igor Smirnov's departure from the post of the presidency at the end of 2011, recognition of Transnistrian independence was nominally the main policy objective declared and pleaded for by the Transnistrian authorities. However, it was not the only one. The Smirnov regime quite frequently spoke of the quasi-state's accession to Russia. Crucially, these two ideas were combined in 2006, when the vast majority of Transnistrians voted in a referendum for the establishment of Transnistria's independence and its subsequent accession to Russia; the Transnistrian authorities declared themselves bound by the people's will. Furthermore, Smirnov made many announcements

Transnistria declared its separation from Moldova on 2 September 1990, but full de facto independence was only achieved later, due to the previously mentioned war with the parent state, which Transnistria won in July 1992. 
on establishing a confederation or, less frequently, a federation with Moldova. At some points he was in favour of Transnistria joining the Russia-Belarus Union, and about a dozen or so times he declared that the quasi-state could join Ukraine. Interestingly, foreign policy goals announced in a given period were often contradictory-for example, even when the Smirnov regime officially followed the results of the 2006 referendum, it also declared another aim. In some cases, Smirnov formulated establishing independence and joining Russia as alternatives, i.e. either Transnistria gained independence or it would become a part of Russia, as expressed in the Russian Duma in 1995 (Ionescu 2002: 54).

Researchers who supported the thesis that Transnistria under Smirnov really sought international recognition as an independent state justified the aforementioned behaviour of the Transnistrian authorities in many ways. They considered it to be tactics or the effect of influence from external factors. They claimed that the Smirnov regime either wanted to make a false impression of real participation in negotiations on the Transnistrian conflict settlement (aimed at maintaining Moldova's territorial integrity); intended to press Moscow to conduct a more favourable policy towards Tiraspol; perceived some solutions, such as a confederation, as a step toward gaining full independence; was influenced by the international community; or simply was forced by its patron-Russia, etc. ${ }^{2}$ However, despite these explanations, Smirnov's position on the international recognition of Transnistrian independence remains highly confusing.

There is also a group of researchers, including the author, who noted that the Smirnov regime enjoyed the status quo very much. This is why they explicitly or implicitly claim the true goal of Tiraspol is to preserve the de facto independence of Transnistria. ${ }^{3}$ In short, the point is that this specific status restricted the use of international law in the region and compared to other solutions, allowed the Transnistrian authorities to enjoy the broadest scope of power, even more so than in a system of internationally recognised independence (which would

See, for example, Kolstø (2006: 734-738). Andrey Safonov—a Transnistrian political scientist and the editor-in-chief of an independent newspaper, Novaya gazeta - simply said in an interview with the author (Tiraspol, 23 June 2011) that Transnistria's behaviour depended on a given situation but the main aim - international recognition — remained unchangeable.

3 See, for instance, King (2001); ICG (2003); Kemp (2004: 46-49); Lynch (2004: 47-48); Belitser (2005: 7). 
mean that international law and international agreements should be honoured, at least to a greater degree). Moreover, it allowed them to derive money from the function of Transnistria, including benefits from smuggling, a profession thriving mainly thanks to the unique status of the Transnistrian region. Ironically, the fact that Smirnov declared other goals - while, in reality, striving to keeping the status quo - can also be explained by tactics and factors of external pressure, in a way similar to the explanations from supporters of the thesis that Transnistria truly sought international recognition as an independent state.

A few of the aforementioned goals of Transnistria under Smirnov were combined by Nicu Popescu (2006: 7, 21-22). He pointed out that the primary objective of the Transnistrian authorities was "to maintain power, as an independent entity or as part of a (con)federated Moldova." This was also ensured by further keeping the status quo. Other experts, such as Jacek Wróbel (2003: 56) and Andrey Devyatkov (2012) noted that Smirnov's aim regarding the status of Transnistria has changed over the course of the 20 years of his rule. The former explained that the Transnistrian authorities sought international recognition of Transnistria's full independence in the 1990s, but thendue to the fact that this objective proved to be impossible to achievethey started to pursue the goal of creating a confederation with the parent state, although a federation could also be accepted. Devyatkov argued that until 1994, Smirnov did not struggle for independence and considered reunification with Moldova, because he was not sure Transnistria could exist as an independent entity at all. Later on, the Transnistrian authorities somehow strengthened their resolve and spoke about obtaining independence, but they still accepted the idea of reintegration into the parent state. In 2006, independence became the only option pursued by Smirnov. But in Devyatkov's opinion, this was motivated by opportunist considerations (triggered mainly by a confrontational policy conducted by Moldova). ${ }^{4}$

All in all, this short summary of research on the position of the Smirnov regime concerning the status of Transnistria shows how deeply divided experts are. The thesis claiming that the Transnistrian region (solely) sought international recognition as an independent state is neither the only one nor the dominant one.

\footnotetext{
See also Protsyk (2006).
} 


\section{YeVgeniy Shevchuk And Transnistria’s InDEPENDENCE}

The new Transnistrian president, Yevgeniy Shevchuk, declares that he follows the people's decision in the 2006 referendum to obtain independence for the Transnistrian region and subsequently join Russia. However, only a few months before the December 2011 presidential elections he presented another position. In a June 2011 interview with Russian Voyennoye obozreniye, ${ }^{5}$ Shevchuk said that the recognition of Transnistria's independence would be the best way for conflict resolution, but he also admitted that it was an unrealistic outcome, because the international community was against such an option. The latter opinion was widespread. For example, in a survey of experts worldwide on scenarios for the development of the Transnistrian conflict, conducted in 2011 by the Kiev Institute of World Policy, most experts estimated the chance of realising an "independence scenario" was close to nil and they ranked it as the least possible solution (Getmanchuk et al. 2011). It is enough to say that even Russia-the quasi-state's defender and breadwinner-was against recognising Transnistria as an independent state. A representative of the Russian Foreign Ministry to the Transnistrian settlement, Sergey Gubarev, put it sharply in April 2011: "Transnistria can live independently from Moldova only if it flies to the Moon" (quoted in Solov'yev 2011). Taking into account these circumstances, Shevchuk suggested postponing Transnistria's formal status. This meant achieving the international recognition of Transnistria's de facto independence and leaving the formal definition of its international status - in other words the full settlement of the Transnistrian conflict-to future generations. Shevchuk believed that this would allow the economy of the Transnistrian region to develop and he mentioned Taiwan as an encouraging example.

Shevchuk may want Transnistria to be internationally recognised (and then became a part of Russia), however, he must be still aware that this task is virtually impossible to achieve. He refers to the 2006 referendum to show that he honours the people's will and to avoid charges of high treason from the opposition. It seems that Shevchuk's real goal is to maintain the present status quo, in other words the status of the quasi-state (but perhaps not because of selfish motivations as

Available at: http://topwar.ru/5098-moldavskiy-gordiev-uzel.html, accessed 4 July 2012. 
was likely in case of his predecessor). He wants to focus on reforms aimed at the socioeconomic revival of the Transnistrian region and by doing so, maintain and enhance Transnistria's statehood.

Importantly, many experts note that Shevchuk's position concerning the status of Transnistria - regardless of its content-is not set in stone, and generally could be negotiated, and the Transnistrian president could eventually support the idea of reintegration with Moldova; ${ }^{6}$ this point of view is supported by the author. Shevchuk is perceived in Moldova, the West, as well as in Russia, as a rational and reasonable politician. He proved himself to be such a person while holding the post of speaker of the Transnistrian parliament (20052009) and the head of the Obnovleniye party (until 2010). The point may be that its quasi-state status hinders the economic development of Transnistria and negatively affects the socioeconomic situation of the Transnistrian population, and this seems to be the main concerns of Shevchuk if one chooses to analyse his statements. ${ }^{7}$ A logical solution would be to abandon the quasi-state status and reunify with the parent state, but the interests of Transnistria, its elites and people, should be sufficiently insured if such a scenario is to be realised. Interestingly, his answer to the question - asked in June 2011 (before the presidential elections) by bloggers and users of his supporters' website - whether he was in favour of reintegration with Moldova, was apparently positive. He said that Transnistria was bound by the international commitments signed by president Igor Smirnov to establish "a common state" with Moldova, mentioning the 1997 Primakov Memorandum and 2003 Kozak Memorandum. ${ }^{8}$

6 Such a thesis was presented, for example, by a former senior official of the European Union and Andrey Devyatkov, Russian political scientist, in an interview with the author (via email, taken respectively on 15 December 2011 and 4 July 2012).

7 Shevchuk paid much attention to the economic situation of Transnistria and the socioeconomic well-being of its ordinary inhabitants, for example, during an interview with William Schreiber and the author (Tiraspol, 2 March 2012). See an article based on the interview (Schreiber, Kosienkowski 2012).

8 Available at: http://eshevchuk.ru/en/content/evgenii-shevchuk-otvetil-na-voprosy-blogerov-ichitatelei-saita-storonnikov, accessed 4 July 2012. 
The Obnovleniye Party and Transnistria’s InDEPEndence

Obnovleniye declares its unwavering support for the idea of Transnistria's independence and-since the 2006 referendum-its subsequent accession to Russia. However, when this political group unexpectedly won the elections and took over parliament in 2005, experts noted that it too may be in favour of reintegration with Moldova. On the one hand, they underlined that Obnovleniye knew that the recognition of Transnistrian independence was an unachievable goal. On the other hand, experts pointed out that reunification could bring economic and political benefits to the party and its sponsorSheriff - the biggest company in Transnistria.

Economic gains were about the stabilisation of economic activity, the opportunity of new investments outside the Transnistrian region, and the possible legalisation of property-bought in a privatisation process conducted by the Smirnov regime-which still belongs to Moldova under international law. Whereas political benefits were about the expansion of political influences, including taking over power in the whole reunified state. According to Nicu Popescu, this factor was even more important than the economic one, who believed that Moldova in reality could offer nothing to Transnistria but political influence. ${ }^{9}$ Georgiy Byanov claimed that Obnovleniye could come to power in the reunified state due to Sheriff's financial resources, exceeding the economic capacities of all other opponents in the whole of Moldova. ${ }^{10}$ Oazu Nantoi bluntly noted that after unification, Sheriff could simply "buy out" the Moldovan parliament. ${ }^{11}$

Importantly, the party declared that the final decision on the status of Transnistria should be made by the Transnistrian population. ${ }^{12}$ It was predicted that the people could be convinced by Obnovleniye to support reunification with Moldova thanks to the strong financial

The author's interview with Popescu, expert at the European Council on Foreign Relations (London), Chișinău, 27 July 2007.

10 The author's interview with Byanov, deputy director of the South-Ukrainian Frontier Research Centre, Kherson (Ukraine), 10 June 2007.

11 The author's interview with Nantoi, expert at the Institute for Public Policy, Chișinău, 3 July 2007.

12 The author's interview with a senior high-ranking politician at Obnovleniye, Tiraspol, 11 June 2007 and with a Western diplomat to Chișinău, 20 August 2007. 
resources of Sheriff (similarly as in the above-mentioned elections in a reunified Moldova).

Time proved that Obnovleniye did not start to promote the reintegration of Transnistria with its parent state. This resulted from internal constraints, such as the strength of the Smirnov regime and the struggle for power in the quasi-state, which emerged as the primary goal of the party, and from external constraints, such as the confrontational policy of the Moldovan authorities. The economic and political benefits that politico-economic elites from Transnistria could gain in case of Moldova's reunification are still in place. But any reintegration plan should appropriately cater these elites' interests to gain their support.

There are other, more palpable signs that Obnovleniye is not necessarily in favour of Transnistria gaining independence (and subsequently joining Russia) and, moreover, that it could hypothetically accept the idea of reunification with Moldova. First, when a senior, high-ranking politician of the party was asked in mid2011 if he understood the notion of independence as the recognition of Transnistria by all other states, and taking a seat among them in the United Nations, his answer was quite vague, but rather negative. He called this an old paradigm and underlined that, first of all, one had to have personal freedom. The politician added that the idea of independence and subsequent accession to Russia mobilised the Transnistrian population, but it must be handled with caution so as not to abuse it, just as one must be careful while boiling an egg. However, there is nothing amid this strange analogy about possible reintegration with Moldova. Instead, he constantly emphasised the desire and need for cooperation between Transnistria and Russia. It appeared that Obnovleniye's politician was in favour of maintaining the status quo. ${ }^{13}$

Second, it seems that political influence and authority are more important for Obnovleniye than the independence of Transnistria. The point is that the party sought and finally got Russia's support in the 2011 presidential elections. For the first time, Russia was in favour of a candidate other than Igor Smirnov. Russia endorsed Anatoliy Kaminskiy, Obnovleniye's candidate and its head, which was supposed to ensure his victory. In return, full loyalty was expected; Kaminskiy himself was perceived as a non-charismatic and manageable person.

13 The author's interview, Tiraspol, 22 June 2011. 
Importantly, Obnovleniye knew that Russia was against Transnistria's independence, as has been already mentioned. Moreover, taking into account that Moldova was moving further towards closer cooperation with the European Union and Romania, a reasonable solution for Moscow would be to not act against Transnistria's reintegration with its parent state. In preemptive outrage against such circumstances, Smirnov accused Moscow and Obnovleniye of betraying Transnistria and based his electoral campaign on an independence slogan "The Republic is not for sale."

Third, one of Obnovleniye's MPs overtly stated in June 2012 that the recognition of Transnistrian independence by Russia would result in a number of negative consequences for both Moscow and Tiraspol. "There is no common border with Russia, there is also no transport corridor, there is the airspace which can be closed by Moldova. How, in the case of such a recognition, will our exports - directed mainly to Europe - suffer? Will we be able to handle it all?" He added that Transnistria should get real-rather than formal-sovereignty and pointed out that the most important fact was that Russia gave the Transnistrian region comprehensive on-the-ground support. ${ }^{14}$

\section{CONCLUSION}

This analysis demonstrates that despite official declarations made by the Transnistrian authorities about seeking internationally recognised independence for their region, this nominal goal is not necessarily a real one. Generally, it can be said that their position concerning Transnistria's status is not so easily identified. The present Transnistrian president, Yevgeniy Shevchuk, and parliament controlled by the party Obnovleniye, in reality, seem to be in favour of keeping the status quo and maintaining the quasi-state's de facto independence. However, it appears that under conditions securing Transnistria's rights and interests, they could truly support the idea of reintegration with Moldova.

Crucially, despite all of these problems with the identification of Transnistria's aims, it can still be defined as a quasi-state containing its main criteria - it resembles a normal state but lacks (substantive)

Available at: http://www.regnum.ru/news/fd-abroad/transdniestria/1540970.html, accessed 10 July 2012. 
international recognition. That is why there is no reason to characterise these entities - as some researchers do-as necessarily striving for recognition as an independent state, which unnecessary limits the research field. It is worth noting that even Scott Pegg, who developed the first coherent concept of quasi-state (calling it the de facto state) and initially claimed that these entities "seeks full constitutional independence and widespread international recognition as a sovereign state" (Pegg 1998: 26), was inclined to drop this opinion in his later research (Pegg 2004: 38-39). Indeed, quasi-states may also seek to join another country, to raise its status within the parent state (gaining autonomy, etc.), to take power over the whole parent state, or to maintain the status quo. In addition, aims can change over time and the nominal goal may vary from the real one.

\section{BIBLIOGRAPHY}

Belitser N., 2005, Civil Society in Transnistria? (A View from Ukraine), EuroJournal.org, http://eurojournal.org/more.php?id=207_0_1_0_ M5 (accessed: 12 Jul. 2012).

Caspersen N., 2011, Democracy, nationalism and (lack of) sovereignty: the complex dynamics of democratization in unrecognized states, "Nations and Nationalism," 17, 2.

Devyatkov A., 2012, Political dynamics in Transnistria in context of the conflict situation, manuscript submitted for publication.

Getmanchuk A., Solodkyy S., Yenin Y., Zarembo K., 2011, Scenarios for the Development of the Transnistria Conflict: Challenges to European Security, Kiev.

ICG, 2003, Moldova: no quick fix, Europe Report 147 (Chisinau \& Brussels, International Crisis Group), http://www.crisisgroup. org/ /media/Files/europe/Moldova\%20147.pdf (accessed: 10 Jun. 2012).

Ionescu D., 2002, From SSMR to the Republic of Moldova \pm pmr, Chisinau.

Kemp W.A., 2004, The Business of Ethnic Conflict, "Security Dialogue," 35,1 .

King Ch., 2001, The Benefits of Ethnic War: Understanding Eurasia's Unrecognized States, "World Politics," 53, 4. 
Kolstø P., 2006, The Sustainability and Future of Unrecognized QuasiStates, "Journal of Peace Research," 43, 6.

Kolossov V., O’Loughlin J., 1999, Pseudo-States as Harbingers of a New Geopolitics: The Example of the Trans-Dniester Moldovan Republic (TMR), in: D. Newman (ed.), Boundaries, Territory and Postmodernity, London.

Lynch D., 2004, Engaging Eurasia's Separatist States: Unresolved Conflicts and De Facto States, Washington, D.C.

Pegg S., 1998, International Society and the "De Facto” State, Aldershot. —, 2004, From De Facto States to States-Within-States: Progress, Problems, and Prospects, in: P. Kingston, I.S. Spears (eds.), StatesWithin-States: Incipient Political Entities in the Post-Cold War Era, New York.

Popescu N., 2006, Democracy in Secessionism: Transnistria and Abkhazia's Domestic Policies, Policy Paper (Budapest, Central European University \& Open Society Institute), http://www.policy. hu/news/NPopescu-PS/22 (accessed: 10 Jul. 2012).

Prostyk O., 2006, Moldova's Dilemmas in Democratizing and Reintegrating Transnistria, "Problems of Post-Communism," 53, 4.

SchreiberW., Kosienkowski M., 2012, Cautious Optimismfor Transnistria, New Eastern Europe, April 5, http://www.neweasterneurope.eu/ node/277 (accessed: 5 Jul. 2012).

Solov'yev V., 2011, Konflikt na Dnestre poprobuyut razmorozit', Kommersant, 29 April, http://www.kommersant.ru/doc/1631523 (accessed: 2 Jul. 2012).

Steinsdorff S. von, Fruhstorfer A., 2012, Post-Soviet de facto states in search of internal and external legitimacy. Introduction, "Communist and Post-Communist Studies," 45.

Wróbel J., 2003, Transnistria, in: Armed conflicts in the post-soviet region. Present situation. Prospects for settlement. Consequences, CES Studies 9 (Warsaw, Centre for Eastern Studies), http://www.osw. waw.pl/sites/default/files/PRACE_9.pdf, (accessed: 10 Jul. 2012). 